ISSN: 1641-4713; e-ISSN: 2081-1160

DOI: https://doi.org/10.36551/2081-1160.2021.27.49-74

\title{
O Percurso Invisível de Açorianos no Brasil do Século XIX
}

\author{
The Invisible Journey of Azoreans in 19th Century Brazil
}

\author{
Fabiene Passamani Mariano \\ Instituto Federal do Espírito Santo - Ifes \\ ORCID ID: https://orcid.org/0000-0002-3049-0536 \\ E-mail: fabienepassamani@gmail.com \\ Maria Cristina Dadalto \\ Universidade Federal do Espírito Santo - Ufes \\ ORCID ID: http://orcid.org/0000-0002-7925-3929 \\ E-mail: mcdadalto@gmail.com
}

Recepción: 29.11.2020

Aprobación: 15.06.2021

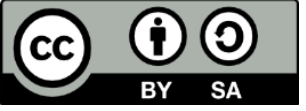

Resumo: O início do século XIX foi um período de intensas mudanças políticas, econômicas e socioculturais no Brasil, decorrentes de uma nova mentalidade de desenvolvimento da Colônia, posta em curso após a chegada da família Real Portuguesa. Com essa nova perspectiva, a Capitania do Espírito Santo despontou no cenário nacional e, em 1813, foi fundada a Colônia Agrícola de Viana, na qual foram fixados imigrantes portugueses naturais das Ilhas dos Açores. As famílias açorianas, além de buscarem sucesso econômico e social, também trouxeram em suas bagagens culturais a Festa do Divino Espírito Santo. O debate, em questão, objetiva a descrição e a análise do processo de povoamento do qual participaram os açorianos estabelecidos na cidade de Viana-ES. Diferente do que ocorre em outras localidades do Brasil (especialmente na Região Sul), a produção de pesquisas e de trabalhos acadêmicos sobre o assunto ainda é restrita e bastante recente. Contudo, pouco a pouco, os açorianos têm sido incluídos na configuração do mosaico identitário capixaba. O marco teórico-metodológico deste artigo está fundamentado na revisão crítica de fontes bibliográficas sobre os açorianos, no contexto do Espírito Santo.

Palavras-chave: Viana, Espírito Santo, colonização, imigração, Açorianos.

Abstract: The beginning of the 19th century was a period of intense political, economic and socio- 
cultural changes in Brazil, arising to a new mentality of development of the Colony, put in place after the arrival of the Royal Portuguese family. With this new perspective, the Captaincy of Espírito Santo emerged on the national scene and, in 1813, the Agricultural Colony of Viana was founded, in which Portuguese immigrants from the Azores Islands were settled. Azorean families, in addition to seeking economic and social success, also brought in their cultural baggage the Holy Spirit Feast. The debate in question aims at describing and analyzing the settlement process in which the Azoreans through took part in the city of Viana-ES. Unlike what happens in other parts of Brazil (especially in the South), the production of research and academic papers on the subject is still limited and quite recent. However, little by little, the Azoreans are included in the configuration of the Espírito Santo identity mosaic. The theoretical-methodological framework of this article is based on the critical review of bibliographical sources about the Azoreans, in the context of Espírito Santo.

Keywords: Viana, Espírito Santo, colonization, immigration, Azoreans.

\section{INTRODUÇÃO}

A emigração açoriana para o Brasil, iniciada em meados do século XVI por incentivo da Coroa Portuguesa, tinha como finalidade recrutar famílias para o processo de colonização do território brasileiro. Nos dois séculos seguintes, foram intensificados os incentivos políticos a esse movimento migratório, com a oferta de transporte marítimo e doação de terras. Essa iniciativa ocasionou um significativo aumento no aliciamento de colonos. Segundo Grosseli: "A imigração de milhares de habitantes das Ilhas Açores e Madeira para o Brasil foi também em outras províncias um dos primeiros fenômenos organizados de transferência de grandes grupos de europeus para o país" (2009, p. 183).

O século XVII foi marcado pela numerosa e intensa saída de açorianos rumo ao Brasil, tendo como principais destinos algumas Capitanias do Norte e Nordeste (Pará, Maranhão, Pernambuco e Bahia). O processo era, na maioria das vezes, organizado pela Coroa Portuguesa, visando suprir seus próprios interesses políticos. A partir da segunda metade do século XVIII, seguindo também pelo século XIX, por questões legais, a emigração de açorianos para o Brasil passou a ocorrer de forma mais moderada. De acordo com Cordeiro e Madeira: "a promulgação da lei de 20 de março de 1720, com aplicação nas ilhas, constituiu forte entrave à livre circulação de pessoas entre o Reino e o Brasil, ao exigir uma justificação documental a todos os que para ali pretendessem deslocar-se" (2003, p. 107).

Apesar das restrições legais, a Coroa continuou apoiando e promovendo o movimento migratório de açorianos para o Brasil, visando suprir as necessidades de povoar, defender e colonizar as regiões fronteiriças do Norte (Maranhão e Pará) e do Sul (Sacramento, Santa Catarina e Rio Grande do Sul). Tal atitude, 
mesmo contraditória, também atendia simultaneamente as demandas dos ilhéus açorianos e das autoridades dos Açores, pois a movimentação de famílias açorianas para o Brasil se apresentava como um socorro imediato às dificuldades socioeconômicas vivenciadas no arquipélago. De acordo com Matos (2013), entre as principais motivações da emigração açoriana para o Brasil estavam: as limitações do território; as dificuldades econômicas geradas pelas crises cíclicas cerealíferas; o tipo predominante de propriedade, envolvendo seu tipo de exploração e o atraso tecnológico. Além das questões sociais e familiares ocasionadas pelo aumento demográfico no arquipélago.

O movimento colonizador, intensamente retomado em meados do século XVIII, foi o responsável por grande parte do povoamento do Brasil meridional, com destaque para o território de Santa Catarina. Porém, mais uma vez, a emigração de açorianos sofreu outra intervenção legal (a lei de 4 de julho de 1758). A lei em questão, sob o argumento de escassez de mão de obra nas diversas ilhas dos Açores, limitava o processo migratório, objetivando a permanência de trabalhadores nas ilhas para suprir as necessidades internas.

Segundo Piazza (1998), o pedido de emigração para o Brasil também surgia da inciativa dos próprios açorianos, sobretudo a partir do século XIX. Isso se justificava pela instabilidade geográfica das ilhas, que sofriam constantes abalos sísmicos e erupções vulcânicas. Além disso, os problemas relacionados às intempéries e à pressão demográfica ocasionavam escassez de alimentos, dificultando ainda mais a possibilidade de uma vida digna da população.

O movimento migratório oficial de famílias açorianas para o Brasil somente foi novamente retomado no início do século XIX e durou aproximadamente duas décadas. Alguns fatores como o interesse da Coroa Portuguesa em continuar ocupando o litoral do Brasil (a fim de evitar a invasão e a exploração de terras por estrangeiros) e a pressão das autoridades políticas dos Açores (que encaravam a emigração como a uma rápida resposta à crise socioeconômica gerada pelo excedente populacional) foram decisivos nesse processo e se faziam presentes no texto do Decreto de $1^{\circ}$ de setembro de 1808 (Presidência da República, 1808):

Sou servido ordenar que das Ilhas dos Açores, se mandem vir 1.500 familias ou um proporcional numero de homens e mulheres em termos de casar, tirado, quanto ser possa, voluntariamente das mesmas Ilhas para se transplantarem para a Capitania do Rio Grande, onde ordeno ao respectivo Governador e Capitão General, lhes mande distribuir pequenas sesmarias que hajam de cultivar, favorecendo quanto ser possa o seu Estabelecimento, na firme esperança que dahi haja de resultar um grande augmento de povoação, com que depois não só resulte o acrescimo de riqueza e prosperidade da mesma Capitania, mas se segure a sua defeza em tempo de guerra. 
Além do que já foi mencionado, cabe destacar os efeitos gerados pelo Decreto de 16 de fevereiro de 1813 que isentava os açorianos e seus filhos que se estabelecessem no Brasil do serviço militar e de milícias, o que se destacava como um dos fatores da emigração, uma vez que havia tensões políticas e fugas do recrutamento militar por parte da população local. De acordo com o referido Decreto, essas providências eram servidas por "um efeito paternal" e tinham por objetivo beneficiar os "fiéis vassalos" do Príncipe Regente e, por consequência, auxiliar o aumento populacional e promover a prosperidade nacional brasileira. Entretanto, mesmo com todos os incentivos que os açorianos recebiam ao emigrarem, ao se instalarem no Brasil, eles continuaram vivendo sob péssimas condições durante longo tempo (Fortes, 1999). Eram em sua maioria pobres, salvo raras exceções.

O Espírito Santo, por sua vez, foi incluído na rota desse processo migratório apenas na segunda década do "Oitocentos". A partir da continuidade do projeto político instituído pela Coroa Portuguesa, com o objetivo de colonizar, explorar economicamente e povoar a Capitania com europeus, foi estabelecido o primeiro grupo de imigrantes açorianos na localidade. Essa mobilidade açoriana, pouco conhecida e estudada na historiografia sociocultural brasileira e internacional, foi protagonizada por aproximadamente 53 famílias (cerca de 250 pessoas) vindas daquele arquipélago entre os anos de 1812 e 1814 (Mariano, 2019). Eram sujeitos que vivenciavam no território açoriano processos de grande crescimento demográfico, fome e falta de trabalho - situação similar à de centenas de milhões de europeus.

São inúmeras as pesquisas e os registros produzidos pelas universidades portuguesas que indicam o início da emigração açoriana para o Brasil, sem citar a existência desse grupo de açorianos enviados para o Espírito Santo. A conferência proferida pelo professor Carlos Guilherme Riley ${ }^{1}$ em Toronto, no ano de 2000, é reveladora desse reduzido conhecimento:

Em rigor estamos perante um fenómeno migratório de índole colonial, isto é, determinado por decisões políticas da coroa portuguesa. Num sentido mais preciso e restritivo do termo, a emigração açoriana para o Brasil só se virá a processar no século XIX, depois da antiga colónia soltar o seu "grito do Ipiranga" e uma vez consolidado o Liberalismo em Portugal após a guerra civil de 1828-34. Então sim estavam criadas as condições necessárias para que os ilhéus comecem a embarcar, por sua livre e espontânea vontade, em direcção às terras da nova nação independente. (Riley, 2003, p. 145)

\footnotetext{
${ }^{1}$ Conferência proferida na Robarts Library, no dia 17 de novembro de 2000, promovida pelo Departamento de Português e Espanhol da Universidade de Toronto, no escopo do ciclo de conferências "A presença portuguesa no Brasil nos últimos 500 anos" (Riley, 2003).
} 
Silva (2012) indica, contudo, que desde o século XVI colonos açorianos estavam presentes no Rio Grande do Sul e em Santa Catarina, em emigração controlada pela Coroa com o objetivo de povoamento. Esclarece também que após a Independência brasileira, é que a emigração passou a ser espontânea. Razera (2016), Silva (2019), Sousa e Ferraria (2009) defendem que em parte desse período, logo após a publicação do decreto do Visconde de Sá Bandeira, de 10 de dezembro de 1836, proibindo o tráfico de escravos na monarquia portuguesa, houve uma rearticulação dos traficantes em busca de suprir mão de obra para os latifundiários brasileiros.

Teve início, à época, segundo a definição desses pesquisadores, um modelo de "escravatura branca", por meio da qual açorianos eram seduzidos a emigrar para o Brasil. Eles eram transportados em navios, a partir de negociações feitas por meio dos engajadores - tal como foram renomeados os traficantes de escravizados africanos - juntamente com comandantes de navios, fazendeiros e colonos portugueses.

A indicação do período pós-independência como um possível marco da emigração açoriana espontânea para o Brasil demonstra desconhecimento sobre a existência do grupo assentado no Espírito Santo, no início do século XIX. Complementa essa ausência, a radicação das informações aos espaços do território brasileiro definidos como receptores de imigrantes açorianos: Santa Catarina, Rio Grande do Sul, Maranhão. Também é Riley (2003) quem nos oferece a dimensão desse padrão informacional:

A partir deste período, altura em que o eixo do império se desloca do Índico para o Atlântico sul e São Salvador da Baía substitui a cidade de Goa como capital do ultramar português, as ilhas não só apoiam as "torna viagens" do Brasil como os próprios ilhéus (em particular os do Pico, Faial e Graciosa) participam no processo de construção do espaço brasileiro, designadamente na consolidação do povoamento das suas regiões fronteiriças setentrionais (Maranhão) e meridionais (Santa Catarina). Num sentido amplo do termo, podemos situar aqui os primórdios da emigração açoriana para o Brasil. (Riley, 2003, p. 144)

Outras fontes reforçam a invisibilidade ${ }^{2}$ do grupo de açorianos assentado na Capitania do Espírito Santo. Ao analisar os ritmos e os destinos da emigração açoriana para o Brasil, Rodrigues e Rocha (2008) situam a emigração açoriana colonizadora a partir do início do século XIX. Eles explicam que o conde de Aguiar, no Rio de Janeiro, em 1812, esclarecia a D. Miguel Pereira Forjaz que havia um levantamento de 1812 no qual, "em São Miguel, estavam alistados 42 casais, perfazendo 194 pessoas, que seguiriam voluntariamente para o Rio de Janeiro" (Rodrigues \& Rocha, 2008, p. 256).

\footnotetext{
${ }^{2}$ A invisibilidade social (individual ou coletiva), de caráter simbólico e/ou material, pode ocorrer em variados níveis (social, afetivo, jurídico), não se configurando como uma categoria e sim como uma realidade de onde surge a percepção de "desprezo social" (Honneth, 2006).
} 
Desses 42 casais aportados no Rio de Janeiro, existe a possibilidade de que alguns tenham se deslocado posteriormente para o Espírito Santo, contudo não encontramos, até o presente, documentação que confirme essa hipótese. De certo, o que muito há em comum entre os diferentes estudos sobre o movimento migratório açoriano para o Brasil, Estados Unidos da América e Canadá é que se concentram, sobretudo, na manutenção das raízes açorianas através da transmissão de suas tradições culturais e, principalmente, de suas práticas religiosas.

A onda emigratória envolvendo a população das Ilhas dos Açores $^{3}$ no século XIX com destino ao Novo Mundo tinha quase sempre uma escolha difícil a sustentá-la: continuar junto às suas histórias, hábitos e memórias com os seus ou deslocar-se. As duas alternativas não se apresentavam de modo fácil: as famílias (ou indivíduos) tinham de decidir entre manter-se na pobreza que rondava grande parte dos habitantes, com oferta escassa e pouco rentável de trabalho nos Açores, ou lançar-se ao desafio da promessa de uma vida próspera em um território desconhecido.

Segundo Gibney (2009), um dos fatores que promove a mobilidade das pessoas para outros países é a tentativa de encontrar mais e melhores oportunidades econômicas para si e para seus familiares. Tal processo movia os açorianos que optavam pela emigração: eles acreditavam na possibilidade de romper o ciclo vicioso de privação em que viviam. Para Flores (2000, p. 14) o imaginário açoriano era nutrido de boas expectativas relacionadas ao sonho de embarcar para o Brasil, afinal as ilhas eram pequenas "mas o mundo vinha até eles, trazido naqueles navios. E eles imaginavam que por meio daquelas embarcações poderiam ir ver o mundo".

Sayad (2000) assegura que a falta de trabalho constrange centenas de milhares de pessoas a renunciar ao lugar onde está estabelecida a sua história cultural, geográfica, biográfica e afetiva. As repercussões do processo emigratório e imigratório para o sujeito provocam no seu cotidiano, no território de assentamento, recordações do tempo vivido em sua terra natal, de modo a tentar manter tradições e práticas socioculturais que permitam o sentido de si em suas raízes.

A imaginação da imigração, como uma promessa de vida melhor, permeia a teia de relação de famílias e amigos que buscam, em território diverso

\footnotetext{
${ }^{3} \mathrm{O}$ arquipélago de Açores é constituído por nove ilhas - Santa Maria, São Miguel, Terceira, Graciosa, São Jorge, Pico, Faial, Flores e Corvo - descobertas, entre os anos de 1427 e 1452, por navegadores lusitanos ligados à Coroa Portuguesa. Localizadas na porção nordeste do Oceano Atlântico, as ilhas contam uma extensão territorial somada em aproximadamente $2300 \mathrm{~km}^{2}$, estando situadas a aproximadamente $2000 \mathrm{~km}$ da Península Ibérica.
} 
daquele que compõe a sua história, um antídoto contra as mazelas da vida em curso. Para Becker (2009), ao se reflexionar sobre os sujeitos de grupos pré-definidos é importante entendê-los com base na comunidade interpretativa que os envolve.

Isso porque as representações produzidas variam nas particularidades dos grupos, sendo elaboradas nos significados das práticas sociais, nas trocas e interações entre o individual e o social. Dadalto (2015) citando a Jovchelovitch (1995), afirma que as representações conformam crenças, valores, atitudes, opiniões e imagens, configurando um sistema de crenças que cada sociedade ou grupo compartilha entre si, permitindo a comunicação ou a troca de sentido entre seus membros.

$\mathrm{Na}$ conjuntura de construção de novo projeto de vida, em novembro de 1812, um grupo de açorianos partiu de seu território com destino à Capitania do Espírito Santo, que recebia seu primeiro grupo de imigrantes, com o objetivo de fundar a Colônia Agrícola de Viana, numa região antes conhecida como Sertão de Santo Agostinho. Em seus baús biográficos carregavam sonhos, desejos, tradições culturais e religiosas, hábitos e costumes.

Cerca de 50 famílias de "ilhéus", ou "casaes de ilhéos" dos Açores, como eram denominados nos documentos oficiais, foram abrigadas no Sertão de Santo Agostinho, onde iniciaram seu processo de inserção socioeconômica, geográfica e cultural. Entre eles, permaneciam, de modo fervoroso, as tradições envolvendo a religiosidade católica - o que ficou evidenciado por meio da construção da Igreja Matriz Nossa Senhora da Conceição, em 1815, e da Festa do Divino Espírito Santo, ${ }^{4}$ celebrada pela primeira vez em 1817.

Nesse sentido, este $\operatorname{artigo~}^{5}$ objetiva a descrição e análise do processo de povoamento do qual participou esse grupo de açorianos na Capitania do Espírito Santo, situando-o no contexto histórico brasileiro do início do século XIX. O debate, em questão, se concentra nas bases que consolidaram a cultura açoriana no Espírito Santo, traduzida, no presente, pela realização da Festa do Divino Espírito Santo na cidade de Viana.

Os eventos fundamentais do processo migratório, que resultou na fundação da Colônia Agrícola de Viana, no ano de 1813 - uma iniciativa pioneira da

\footnotetext{
${ }^{4}$ A Festa do Divino Espírito Santo é uma tradição muito forte entre os açorianos. Ela continua sendo realizada em Viana graças à união entre tradição familiar e religiosidade católica, direcionada à transmissão dos principais rituais simbólicos da Festa, ao longo das gerações.

${ }^{5}$ Este artigo tem como base a Tese de Doutorado intitulada "A Festa do Divino em Viana no século XXI: memórias afetivas na construção de uma açorianidade capixaba", defendida por Fabiene Passamani Mariano em 2019 no Programa de Pós-Graduação de História da Universidade Federal do Espírito Santo.
} 
Coroa Portuguesa no Brasil - são apresentados por Levy (1974). Ele esclarece que as experiências de colonização por imigração estrangeira no país tiveram origem no começo do século XIX, com o estabelecimento das colônias de Santo Agostinho (Espírito Santo), em 1812, e a de Nova Friburgo (Rio de Janeiro), em 1819.

A partir de um apanhado historiográfico político e socioeconômico, tendo como suporte um marco teórico-metodológico fundado na revisão crítica dos estudos sobre os açorianos no contexto do Espírito Santo, buscamos evidenciar como o movimento migratório de naturais do arquipélago de Açores foi responsável por instaurar as bases que consolidaram a cultura açoriana no Espírito Santo, na cidade de Viana ${ }^{6}$ Contudo, resta esclarecer, que a documentação sobre a história do Espírito Santo, referente às primeiras décadas do século XIX, é permeada por inúmeros hiatos.

De tal modo, elegemos alguns acontecimentos como norteadores metodológicos, no que tange à busca de respostas que fundamentam este artigo. Entre esses, pontuamos algumas ações políticas empreendidas nos Governos de Silva Pontes (1800-1804), Manoel de Albuquerque Tovar (1804-1811) e Francisco Alberto Rubim (1812-1819) na Capitania do Espírito Santo. Convém destacar que os documentos mais significativos para o desenvolvimento deste estudo pertencem ao acervo do Arquivo Público do Estado do Espírito Santo (APEES). ${ }^{7}$ Entre a documentação acessada e selecionada, ressaltamos: a "Série Accioly", a "Série 751" e as "Novas Séries", todas pertencentes ao "Fundo Governadoria".

\section{Dos AÇORES Ao SERTÃo de SANTo Agostinho}

A ocupação do Espírito Santo até o primeiro quartel do século XIX estava concentrada numa estreita faixa litorânea que distava, no máximo, de vinte quilômetros da costa. O relevo acidentado do interior do território e as limitações de transporte e comunicações estabeleciam-se como relevantes fatores a demarcar o crescimento econômico regional (Pimentel, 2008). O decreto do príncipe regente

\footnotetext{
${ }^{6}$ Dados atuais sobre Viana-ES: cidade localizada na região metropolitana, distante cerca de $20 \mathrm{~km}$ de Vitória (capital do estado do Espírito Santo). Possui uma área territorial de $312.279 \mathrm{~km} 2$ e população estimada em 79.500 pessoas, de acordo com o censo do Instituto Brasileiro de Geografia e Estatística (IBGE, 2020).

${ }^{7}$ Alguns documentos referentes ao período selecionado estavam em condições precárias, tanto para o manuseio, quanto para leitura. Muitos deles estavam ilegíveis, manchados ou parcialmente destruídos por traças.

${ }^{8} \mathrm{O}$ "Fundo Governadoria" é um acervo composto, em quase sua totalidade, por correspondências recebidas e expedidas pela governadoria do Espírito Santo (disponível em https://ape.es.gov.br/governadoria).
} 
ao governador Silva Pontes ${ }^{9}$ é revelador desse processo. Nele era declarada a intenção de "reanimar a quase extinta capitania do Espírito Santo" (Santos, 2005, p. 48).

Nessa atmosfera socorrista, o governador Silva Pontes propôs seu primeiro projeto de revitalização, liberando, em 1800, a navegação do Rio Doce ${ }^{10}$ e abolindo as restrições impostas durante o século XVIII a essa porção territorial da Capitania. Propôs, ainda, a concentração das exportações no Porto de Vitória, visando ao desenvolvimento local e das regiões vizinhas, a partir da centralização da administração na Capital. Entretanto, esse projeto audacioso de desenvolvimento regional não foi adiante.

O sucessor de Silva Pontes, Manoel de Albuquerque Tovar, ${ }^{11}$ também buscou novas possibilidades de exploração econômica para a Capitania, adotando medidas políticas que primavam pelo desenvolvimento econômico. A exemplo, a construção de uma postura atuante na dinâmica mercantil colonial por meio da produção de gêneros de primeira necessidade.

Cabe ressaltar que a Capitania do Espírito Santo era economicamente ativa, levando em consideração a lógica do sistema escravista vigente, bem como a produção local relativamente diversificada e complexa (Carvalho, 2008, p. 65). Entretanto, o Brasil do século XIX apresentava uma trama de intensas disputas de poder e isso afetava diretamente sua organização política e administrativa. A economia "continuou primordialmente, em consonância com o mercado externo e era virtualmente um reflexo deste. Isso tinha consequências profundas também para a organização social e política do país” (Banck, 2011, p. 30). Além disso, a instalação da Família Real Portuguesa no Brasil instaurou significativas mudanças no funcionamento da Colônia. Em meio a essas mudanças, ressaltamos a elevação do Brasil de Vice-Reino a Reino Autônomo, ${ }^{12}$ o incentivo à imigração

\footnotetext{
${ }^{9}$ Antônio Pires da Silva Pontes Leme, o governador Silva Pontes, foi nomeado em 1797, quando a Capitania do Espírito Santo estava sob o domínio administrativo da Capitania da Bahia, porém, só tomou posse em março de 1800, permanecendo no cargo até 1804.

${ }^{10}$ Silva Pontes também assinalou a necessidade de povoar a região do Rio Doce com casais de Minas ou vindos das ilhas dos Açores (Santos, 2005), sendo este um pensamento pioneiro no sentido de incentivar a imigração estrangeira para o Espírito Santo.

${ }^{11}$ Manoel de Albuquerque Tovar, Sargento-Mor de Cavalaria, Coronel de Milícias e Fidalgo da Casa Real, governou a Capitania do Espírito Santo entre os anos de 1804 a 1811.

${ }^{12} \mathrm{O}$ príncipe regente e futuro rei D. João VI, ao final do reinado de D. Maria I (sua mãe), elevou, em 1815, o Brasil da condição de vice-reinado colonial à de Reino Autônomo, intitulando-se Príncipe-Regente de Portugal, Brasil e Algarves. Foi um período de grandes tensões, devido à precariedade vivida por Portugal em oposição ao desenvolvimento do Brasil, sua ex-colônia. A cidade do Rio de Janeiro tornou-se a capital do Reino, ou simplesmente a Corte. O Reino Unido de Portugal, Brasil e Algarves foi desmembrado em 1822, por ocasião da independência do Brasil, proclamada por D. Pedro de Alcântara e Bragança (fillho de D. João VI), futuro D. Pedro I, Imperador do Brasil.
} 
europeia, o fim do pacto colonial e a criação de Ministérios (de Negócios do Reino, da Guerra, da Marinha e Ultramar e de Negócios Estrangeiros).

Entre as ações políticas adotadas, visando estabelecer um maior controle administrativo do território brasileiro, destaca-se a criação, em abril de 1808, da Intendência Geral da Polícia da Corte e do Estado do Brasil - instituição extremamente relevante para o desenvolvimento da Colônia e, particularmente, para a inserção da Capitania do Espírito Santo no cenário político nacional.

Com a criação da Intendência Geral de Polícia, por iniciativa do intendente Paulo Fernandes Viana, chegaram em diferentes localidades do Brasil imigrantes portugueses naturais das Ilhas dos Açores. Entrementes, registros de Viana relatavam que apenas os açorianos trazidos para a Capitania do Espírito Santo alcançaram o sucesso esperado nessa primeira leva específica:

Por minhas instâncias projetei e consegui que das ilhas dos Açores se transportassem casais de ilhéus, que viessem aumentar a povoação branca deste país; e vieram com efeito muitos à custa das rendas da Intendência, pagaram de frete de $50 \$$ a $70 \$$ por cada cabeça, exceto das crianças de peito, arranjaram-se com mesadas por dois anos nesta província (Rio de Janeiro), na de São Paulo, Porto Seguro e Capitania do Espírito Santo; a todos se deram casas, terrenos, ferramentas, carros e bois, ou cavalgaduras, e ainda que em nenhuma parte prosperassem tanto como na Capitania do Espírito Santo pela inconstância de seus gênios e pouco amor ao trabalho, na Capitania, pelos cuidados do governador que ali estava, o capitão de mar e guerra Francisco Alberto Rubim, se erigiu com estes casais a linda povoação de Viana ${ }^{13}$ com casas de telhas para cada um, igreja e capelão curado, que hoje está já com freguesia separada da Vitória, com côngrua e cirurgião de ordenado pago pela mesma Intendência, que estão com seus títulos correntes de sesmaria, que já chegam a cinquenta e quatro, e têm-se ali promovido entre si e com famílias do país dezoito casamentos e com estes e com os mais espalhados. (Viana, 1892, p. 378)

O discurso de sucesso dos açorianos instalados em Viana, entretanto, é divergente dos registros de viajantes estrangeiros que estiveram na região. De acordo com o príncipe Maximiliano, "essa gente, que vive em grande pobreza, queixa-se amargamente de miséria; fizeram lhe magníficas promessas, que não foram cumpridas" (Wied-Neuwied, 1989, p. 146). A esse respeito, destacamos também a descrição de Saint-Hilaire (1974) sobre a povoação:

Vianna se compunha de cerca de 60 casas, porem não eram reunidas em um só grupo. Algumas dellas construidas de terra e cobertas de palha foram feitas. Dentro das proprias posses e outras sobre uma colina separada. Ao redor das casas a matta foi derrubada e substituida por plantações de milho, de arroz, de feijão e de mandióca. No extremo de

\footnotetext{
${ }^{13}$ De acordo com Derenzi (1965), o povoado recebeu o nome de Viana em homenagem ao intendente de polícia, Paulo Fernandes Viana, tio e protetor de Rubim, do Espírito Santo e da Colônia que se fundava sob seu patrocínio. Ressalta, também, que o Governador Rubim se aproveitava politicamente de seu parentesco com Paulo Fernandes Viana, explorando tal circunstância em benefício de sua administração.
} 
toda a zona cultivada ha uma ligeira elevação cujo alto apresenta uma larga plataforma onde se construiu a igreja, o presbiterio e tambem uma grande casa destinada ao governador. Deste ponto se avista a leste uma parte das casas de Vianna e do lado de oeste uma grande caserna destinada aos soldados que protegem os colonos contra os ataques dos indígenas. (Saint-Hilaire, 1974, p. 232)

Os relatos dos viajantes evidenciam as intenções políticas subliminares ao discurso oficial. Ao mesmo tempo, reforçam a necessidade latente de debate e reflexão sobre as fontes disponíveis para pesquisa. Em especial, aquelas de governadores e intendentes que participavam do jogo de poder, em busca de descrever o êxito de suas ações que resultassem em prestígio na Corte.

Paulo Fernandes Viana, Intendente Geral de Polícia no Rio de Janeiro, entre os anos de 1808 e 1821, reproduzia em suas ações o pensamento da Corte. Entre suas maiores preocupações estavam o fim da escravidão e movimentos sociopolíticos com vistas ao "embranquecimento"14 populacional da Colônia. O Intendente Viana era considerado a figura política responsável por conectar "o poder central e local pelo Império Luso-brasileiro neste período, além de demonstrar como era um elemento vital para sustento do projeto imperial durante um período de séria erosão da autoridade da coroa Portuguesa" (Lemos, 2008, p. 16).

Também merece destaque a nomeação de Francisco Alberto Rubim da Fonseca e Sá Pereira como governador da Capitania do Espírito Santo. Seu mandato teve início em 1812 e se estendeu até 1819, e ele foi o primeiro governo independente da Bahia. ${ }^{15}$ À frente da Capitania, o governador Rubim, registrou em suas memórias estatísticas ${ }^{16}$ diversos dados sobre a povoação de Viana, que incluem a geografia, a infraestrutura, a demografia e as principais vias de comunicação.

\footnotetext{
${ }^{14}$ De acordo com Guimarães (2012), a grande movimentação de imigrantes europeus no Brasil do século XIX, incentivada por uma política oficial de "embranquecimento", impactou diretamente a sociedade brasileira na construção de seu imaginário nacionalista. De acordo com o autor, esse fato fez com que a elite da época, ao mesmo tempo, promovesse a dinâmica de absorção desses imigrantes (principalmente os europeus), bem como redefinisse os demais trabalhadores a partir de um novo pensamento racista.

15 "Como todas as antigas donatarias e mais as capitanias criadas depois de D. João III, o Espírito Santo, no fim do século XVIII, pertencia à Coroa. À frente de seu governo, encontrava-se um capitão-mor-governador, subordinado aos governadores e capitães-generais da Bahia" (Oliveira, 2008, p. 249).

16 "Memórias Estatísticas" eram relatórios de caráter obrigatório, confeccionados pelos próprios governantes para serem enviados ao Governo Geral do Brasil. Os discursos das memórias estatísticas refletiam o pensamento político da época, em que os dados apresentados sobrevalorizavam as ações dos administradores nomeados pela Coroa. Além disso, expressavam a necessidade de apresentar novas alternativas econômicas, com vistas a mudar a postura da Capitania e assim obter maior independência desta em relação ao governo geral.
} 
Durante seu mandato, Rubim recebeu duas visitas do bispo do Rio de Janeiro, D. José Caetano da Silva Coutinho, nos anos de 1812 e 1819 . No ano de 1819, em sua segunda visita, o bispo Coutinho visitou a região de Viana e, em seus escritos sugere que, após alguns anos da fundação de Viana, a localidade não havia prosperado, apesar dos investimentos do governo local.

Durante a gestão do governador Rubim, foi iniciada a penetração do território através da construção de uma via de locomoção entre o Espírito Santo e Minas Gerais, que apesar de todo o investimento, somente foi concluída no ano seguinte ao término do seu mandato, no ano de 1820.

Em suma, o século XIX foi um período de extrema relevância para a constituição da sociedade capixaba tal como ela se apresenta na atualidade, considerando-se principalmente as ações políticas e seus desdobramentos, que visavam ao desenvolvimento socioeconômico da Capitania. Em especial, o intenso fluxo migratório que trouxe para o Espírito Santo outros grupos de imigrantes europeus e asiáticos.

\section{A CONSTRUÇÃO DA AÇORIANIDADE NO ESPÍRITO SANTO}

Novaes (1964), em sua obra "História do Espírito Santo", relata a seguinte passagem, contada de geração em geração, sobre a chegada dos primeiros imigrantes açorianos no Espírito Santo, em novembro de 1812, na Vila de Vitória:

Desejoso de conhecê-los pessoalmente, o Governador Rubim chamou-os ao Palácio. E notou que, dentre eles, estavam cinco irmãs, mocinhas lindas e esbeltas. Uma, Luísa Aurelia da Conceição, tinha apenas dezoito anos; despertou a atenção de um pajem do Governador, chamado Antônio de Freitas Lira, que não se conteve e alisou delicadamente os cachos maravilhosos da jovem lusitana!... Acontecia, porém, que Rubim não era homem de brincadeiras. Rigoroso nas atitudes, exigia de seus governados inteireza de procedimento. [...] Por isso, Antônio de Freitas Lira, dias após casava-se com Luísa Aurelia. Originou-se, desse modo, na Capitania, a primeira família entre açorianos e brasileiros, a família Lira que, até hoje conserva suas belas tradições de amor ao município e ao Espírito Santo. (Novaes, 1964, pp. 116-117)

Três meses depois de darem entrada na Capitania do Espírito Santo, em fevereiro de 1813, esse grupo de açorianos foi instalado no Sertão de Santo Agostinho. Iniciava assim a fundação e a colonização de Viana. Na época, a localidade pertencia a Vitória e, em sua circunvizinhança, existiam as fazendas de Calabouço, Tanque, Borba, Jucu, Belém, Jucuruaba e Araçatiba. Grande parte desse território estava coberto por matas virgens, era habitado por índios botocudos, ${ }^{17}$

${ }^{17}$ Acerca desse assunto, é valioso o relato do viajante Saint-Hilaire (1974, p. 111): "Todas as numerosas vantagens usufruídas pelos habitantes de Viana eram, na época de minha viagem, 
e se estendia até as fronteiras com Minas Gerais. Atualmente, seu território se encontra bastante reduzido (detalhe da Figura 1).

As famílias açorianas assentadas no Espírito Santo foram alojadas nas proximidades dos rios Santo Agostinho, Formate e Jucu para viabilizar o desenvolvimento da produção agrícola. Convém lembrar que, antes de serem encaminhados ao Brasil, eles habitavam ilhas oceânicas, com temperaturas amenas, clima temperado, praticando a pesca da baleia e a agricultura como formas de sustento.

Figura 1 - MAPA LOCALIZAÇÃo DE Viana No EsTAdo do EsPíRITO SANTO

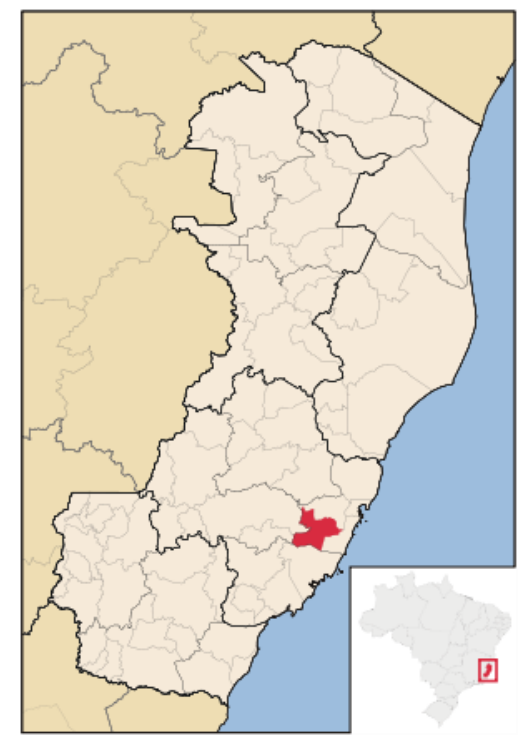

Fonte: https://mapasblog.blogspot.com/2011/11/mapas-do-espirito-santo.html

Desde a viagem de navio, realizada em condições sub-humanas, até a adaptação à "terra prometida" as dificuldades foram muitas. Como em todo processo migratório, alguns indivíduos não conseguiram se adaptar à geografia, ao clima e ao tipo de trabalho que deveriam desenvolver na nova localidade. No caso dos açorianos, essa situação não foi diferente.

Apesar dos benefícios oferecidos pelo Governo, os problemas de adaptação e as promessas não cumpridas geraram descontentamentos que despertavam nos açorianos o desejo de retorno. Um dos desagrados seria a vinda deles para

compensadas tristemente pelo temor que, sem cessar, causava a vizinhança dos índios inimigos. Estes, aliás, se mostravam tão bárbaros que o pavor era bem justificado. Mais ou menos 20 dias antes de minha chegada ao lugar, o Tenente Bom Jardim soube que eles haviam massacrado um colono e raptado um de seus filhos". 
a Capitania do Espírito Santo, quando na verdade, a eles foram prometidos terrenos nas Capitanias de Minas Gerais, Santa Catarina ou Rio Grande do Sul. Além disso, outras questões acentuaram ainda mais essa difícil realidade:

$\mathrm{O}$ ar de Viana, antes dos desbravamentos, que tiveram início logo depois, estava longe de ser salubre; os colonos não estavam acostumados a trabalhar sob sol ardente dos trópicos, e cometeram, logo ao chegar, a imprudência de formar arrozais nos alagadiços, próximos de suas moradias. Muitos homens adoeceram e morreram. As mulheres foram menos sacrificadas; saíam menos que os maridos, e assim não tiveram as mesmas ocasiões de beber águas más, e nem iam aos lugares pantanosos... Assim que viram morrer alguns patrícios os ilhéus se apavoraram e pretenderam retirar-se. A isto, o governador se opôs, alguns fugiram, mas foram trazidos à força armada para Viana; quando de minha viajem, era ainda proibido aos novos colonos irem estabelecer-se em outra parte... (Saint-Hilaire, 1974, p. 109)

Conforme os relatos, a subsistência dessas pessoas implicava numa rápida adequação a esse novo território, entretanto, isso não ocorreu. Essa informação também pode ser confirmada por meio de relatos oficiais do Governo. No ofício de onze de junho de 1822, da Junta Governativa ao ministro José Bonifácio, constava que os açorianos ainda não estavam adaptados e que o investimento do Estado nesses estabelecimentos não teve o retorno esperado:

[...] mas os suplicantes e todos os outros novos Colonos, que vieram das Ilhas dos Açores, têm sentido notável alteração, não estando ainda bem aclimatados: que o perigo, que temem do Gentio é o que geralmente temem todos os Lavradores desta Província e que tendo o Estado já feito considerável despesa com esses estabelecimentos, que tão pouco frutíferos têm sido, porque além destes novos colonos não se terem ainda acostumado ao trabalho da cultura destas terras, muitos / como talvez os Suplicantes / foram tirados de classes, que não eram agricultoras, e por isso tanto mais estranho thes tem sido o manejo rural; não parece dever-se dar aos Suplicantes novos estabelecimentos, e mantenças à custa do Estado. Eles já têm faculdade de mudarem de estabelecimento quando quiserem, e venderem as terras, cabanas, e utensílios, que se lhes têm prestado pela caixa da Polícia. Com esse produto é que os Suplicantes se devem novamente estabelecer: e se o Estado lhes continuar ajudas de custo, nenhum outro deixará de a requerer, visto que os motivos são gerais. (Arquivo Público do Estado do Espírito Santo, 1822)

O ofício justifica, ainda, que os ilhéus não possuíam manejo rural, pois pertenciam a classes sem experiência com a agricultura. Por fim, havia a orientação de que o Estado não distribuísse novas terras e outros benefícios aos imigrantes açorianos instalados em Viana, explicada pelo fato de que, à época da chegada, eles já teriam adquirido o direito de vender as terras e os pertences recebidos do Governo anteriormente e, dessa forma, poderiam aplicar esses recursos na compra de outras propriedades.

O pedido de suspensão de benefício aos açorianos estaria pautado numa possível solicitação de novos auxílios ao Governo por parte dos imigrantes de outras nacionalidades, tendo em vista que eles também estavam enfrentando dificuldades similares. 
Entre os documentos do "Fundo Governadoria" do Arquivo Público Estadual, mais especificamente, na "Série “Accioly" (caixa no 2), foi possível analisar as correspondências recebidas pelo governador Francisco Alberto Rubim e expedidas por D. João, o Príncipe Regente, entre os anos de 1813 e 1817. São documentos relacionados à vinda e à instalação de açorianos no Espírito Santo.

Uma das correspondências analisadas neste estudo foi encaminhada por D. João ${ }^{18}$ em 23 de abril de 1813 e versa sobre o acompanhamento do "mappa" da povoação da capitania do Espírito Santo (Figura 2). ${ }^{19} \mathrm{Na}$ época, a informação prestada pelo Governo da Capitania estimou que a população local estivesse em 18.807 almas, entretanto, esse número foi questionado pelo Príncipe Regente.

A justificativa apresentada para essa discordância seria uma falta de exatidão na confecção do referido "mappa", que possivelmente não havia contabilizado a população das outras vilas da Capitania. Para finalizar, ele concluiu que a Capitania iria crescer pelos "Cazaes de Ilheos", ou seja, pelas famílias açorianas, que ultimamente haviam se estabelecido na localidade.

Outro documento da "Série Accioly" que merece destaque é uma correspondência endereçada ao governador Rubim, em 4 de dezembro de 1813 (Arquivo Público do Estado do Espírito Santo, 1813b), sobre o envio de açorianos à Capitania do Espírito Santo ${ }^{20}$. Em sua inicial, consta a indicação do nome do navio e do mestre da embarcação pela qual eles foram transportados: "Pela Laura Victória, Mestre Manoel Thomé...”. O documento (Figura 3) relata o envio de seis "Casaes de Ilheos" à Capitania, totalizando 23 pessoas.

\footnotetext{
${ }^{18}$ Entre os documentos do período, era comum encontrar correspondências expedidas pelo Príncipe Regente e assinadas pelo Conde de Linhares (D. Rodrigo de Souza Coutinho). Ele fazia parte do $1^{\circ}$ Gabinete do Príncipe Regente no Brasil e era o responsável pela pasta de Negócios Estrangeiros e da Guerra. O Conde de Linhares possuía uma relação íntima com o governador Rubim (Bittencourt, 2008, p. 20).

${ }^{19}$ Transcrição do documento: "Lavrei a Augusta presença de Sua Alteza Real e Princípe Regente Nosso Senhor o ofício de V. $\mathrm{M}^{\mathrm{de}}$. [Vossa Majestade] de 3 de Abril do presente anno, que acompanhou o Mappa da Povoação dessa Capitania que mostra ser actualmente de 18.807 Almas; e fica o Mesmo Senhor sabedor, de que V. $\mathrm{M}^{\mathrm{de}}$. a suppõe maior, por julgar não serem muito exactos os Mappas da Povoação que vem das outras Villas dessa Capitania, e que ella crescera pelos Cazaes de Ilheos que ultimamente ahi se tem estabelecido. Deus guarde a V. $\mathrm{M}^{\text {de }}$. Palácio do Rio de Janeiro em 23 de Abril de 1813. Conde de Aguiar".

${ }^{20}$ Transcrição do documento: "Pela Laura Victória, Mestre Manoel [ilegível] Thomé, remeto a V. S ${ }^{\text {a }}$ seis Casaes de Ilheos, com 23 pessoas, e consta da relação inclusa, assignada pelo oficial maior da Secretaria desta Intendência Nicolao Viegais de Proença, para serem estabelecidos em conformidade das ordens que se tem expedido a este respeito. A passagem deles junta a [ilegível] pessoa, e os filhos them a idade de 12 annos a 24 menos os [ilegível] que he gratuita, enesta certeza pode V. Sa mandar pagar ao Mestre a quantia de 66.000 - que tanto importa as referidas passagens. Rio 4 de dezembro de 1813. Ilmo Francisco Alberto Rubim, Gov. da Capitania do Espírito Sto".
} 
FIGURA 2 - CORRESPONDÊNCIA ENVIADA AO GOVERNADOR RUBIM EM 23/04/1813

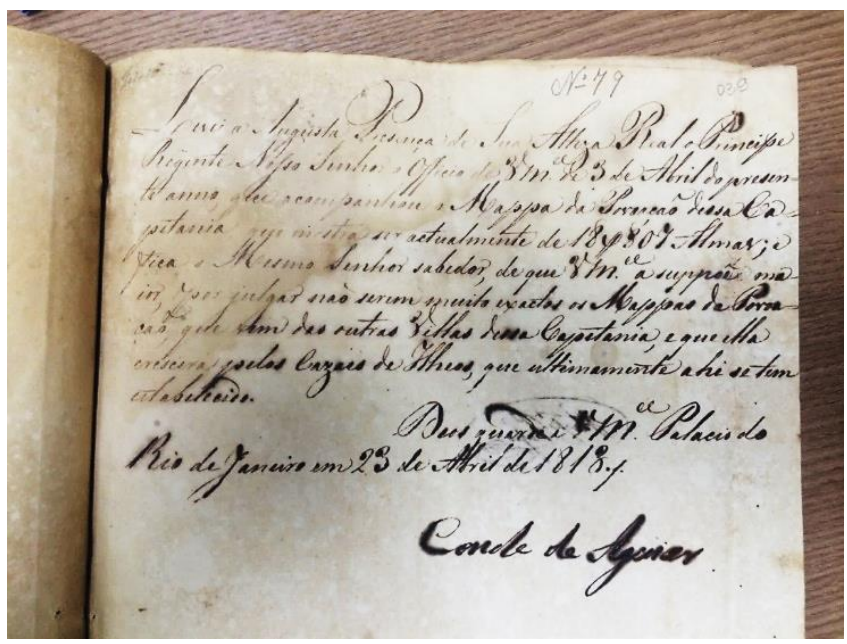

Fonte: Arquivo Público do estado do Espírito Santo, 1813a.

FigURA 3 - CORRESPONDÊNCIA ENVIADA AO GOVERNADOR RUBIM EM 04/12/1813

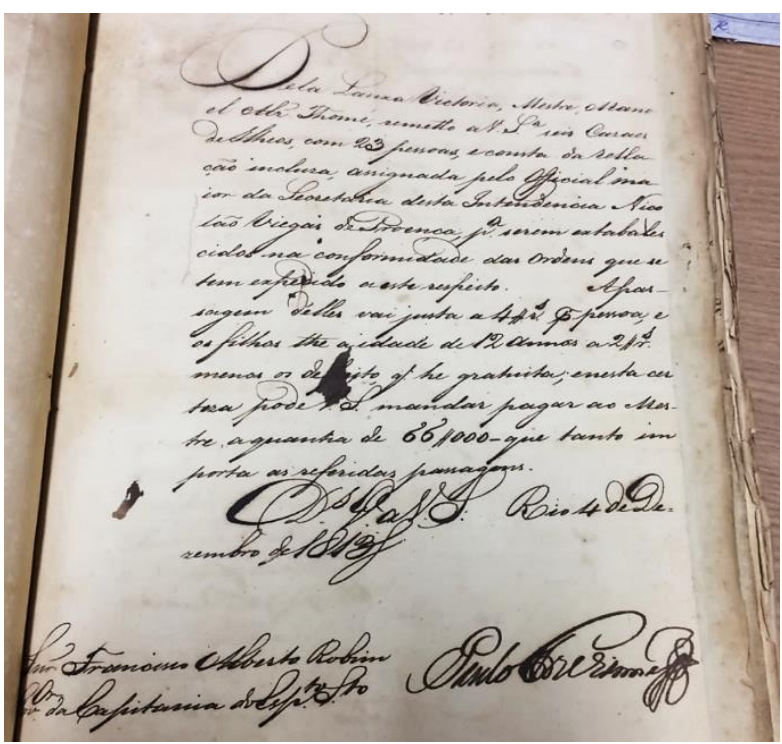

Fonte: Arquivo Público do estado do Espírito Santo, 1813b.

A inicial da correspondência citada (Figura 3) é acompanhada de uma relação nominal que, segundo consta, foi assinada pelo oficial maior da Secretaria da Intendência Geral de Polícia. O documento em questão orientava que os açorianos fossem estabelecidos em conformidade das ordens expedidas a respeito, 
deixando subtendido que esse processo era conhecido pelas autoridades locais. Acrescenta, ainda, que o valor referente às passagens de navio deveria ser pago ao mestre da embarcação.

A documentação anexada à correspondência recebe o título de "Rellação de Casaes de Ilheos que vão para a Capitania do Espírito Santo na Laura Victória do Mestre Manoel Thomé". Nela estão detalhados os dados de cada família encaminhada: nomes, idades e grau de parentesco. Das duas páginas do documento, uma consta os dados de três famílias, totalizando dez pessoas.

Além da "Série Accioly", também analisamos documentos da "Série 751", na qual consta o "Livro de Matrícula dos Ilhéus situados na Povoação de Viana" (Arquivo Público do Estado do Espírito Santo, 1814a), que contém dados acerca das famílias que chegaram ao Espírito Santo de 1812 a 1814. O "Livro de matrícula" é o conjunto de documentos mais específicos que existe sobre os açorianos no estado do Espírito Santo.

Suas páginas estão dispostas em formato de tabelas, contendo, cada uma delas, quatro colunas com informações sobre a data de chegada à Villa (de Vitória), nome, idade e observações (em alguns casos, foram registradas informações sobre casamentos e óbitos). Deram entrada no Espírito Santo, nesses três anos, 245 imigrantes açorianos oriundos de 47 famílias diferentes. Desse total, 116 eram do sexo masculino e 129 do feminino; e 146 eram crianças ou adolescentes.

Em média, as famílias eram compostas por poucos membros e havia agregados na composição de algumas delas, conforme se observa no Gráfico 1 (a seguir). Infelizmente, não localizamos, nos acervos estaduais, documentos com informações mais detalhadas, como a procedência dos imigrantes em relação à Ilha de origem, ${ }^{21}$ e a indicação dos navios ${ }^{22}$ e portos pelos quais eles embarcaram ou desembarcaram, tanto nos Açores, quanto em outras capitanias do Brasil.

Assim que chegavam à Povoação de Viana, as famílias açorianas eram assentadas em pequenas casas e recebiam terras para cultivar. Durante a pesquisa,

\footnotetext{
${ }^{21}$ Sobre a indicação das ilhas de onde partiram os imigrantes açorianos encaminhados para Viana, registrou Wied-Neuwied: "cerca de quarenta famílias, que vieram dos Açores, sobretudo da Terceira e São Miguel, e algumas poucas de Faial” (1989, p. 146).

${ }^{22}$ Nesta pesquisa, analisamos um documento sobre a chegada de 23 imigrantes ao Espírito Santo por meio do Navio "Laura Victoria", no ano de 1813. Entretanto, essa informação não constava do Livro de Matrícula dos Ilhéus e, sim, de uma correspondência enviada pelo Príncipe Regente ao governador da Capitania. Trata-se de uma viagem entre a Capitania do Rio de Janeiro e a do Espírito Santo e, dessa forma, o nome do navio e o porto de origem (nos Açores) continuam desconhecidos.
} 
encontramos a imagem de uma litografia ${ }^{23}$, de autoria de André Carloni ${ }^{24}$, que ilustra esse processo. Na Figura 4, percebemos um terreno desmatado e montanhoso, onde estavam edificados alguns quartéis - que tinham como objetivo proteger a população colonizadora dos ataques indígenas, bastante comuns à região naquela época.

GRÁFICO 1 - DeSEMBARQUE DE AÇORIANOS NO ESPÍRITO SANTO CLASSIFICADOS DE ACORDO COM ANO, SEXO E IDADE

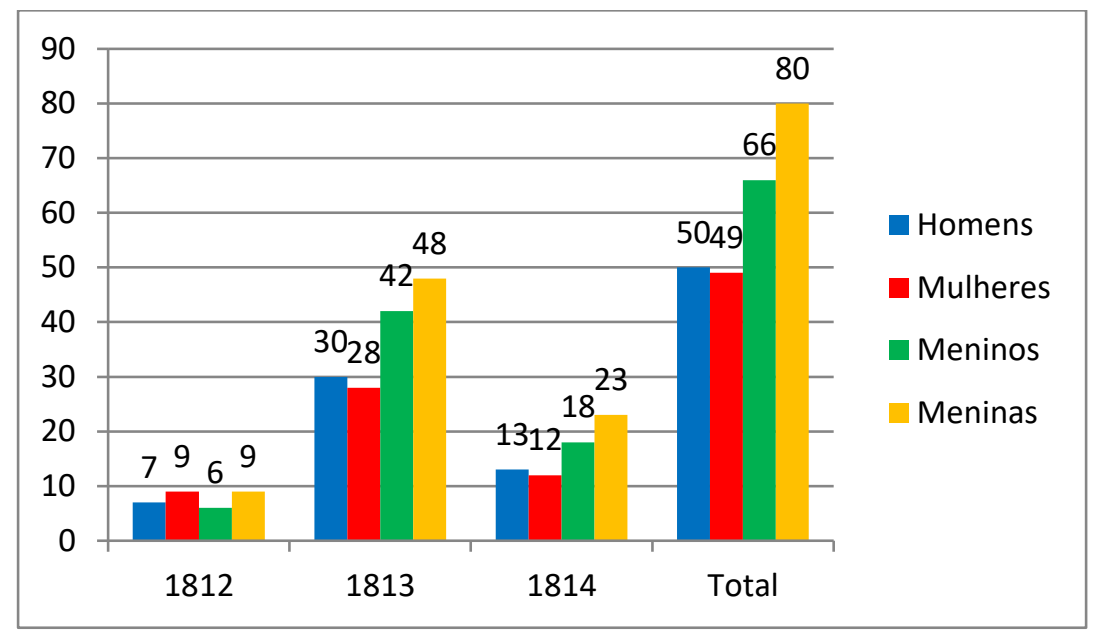

Fonte: Mariano, 2019.

$\mathrm{Na}$ imagem, os quartéis, os rios, as estradas e os espaços destinados à agricultura estão identificados através de letras (maiúsculas e em ordem alfabética) e descritos na barra inferior esquerda da imagem. O título da ilustração, "Prespectiva da Povoação de Vianna a borda do Rio Santo Agostinho na Capitania do Espírito Santo acabada e povoada de Casaes Iléos das Ilhas dos Assores, no Anno de 1813", está inscrito na parte central da barra inferior.

Na margem inferior direita da reprodução consta um texto, baseado num documento de 15 de novembro de 1812, que descreve o tamanho das sesmarias a serem doadas aos casais de ilhéus, identificando-as através de números. Há indicação de que quase todos os terrenos possuíam córregos próximos às casas, bem

\footnotetext{
${ }^{23}$ Litografia é um método de impressão a partir de imagem desenhada sobre base de pedra ou metal. O desenho é feito com materiais gordurosos e a pedra é tratada com soluções químicas e água, que fixam as áreas oleosas do desenho sobre a superfície.

${ }^{24}$ André Carloni nasceu na Itália (Bolonha) no ano de 1883 e, em 1891, emigrou para o Espírito Santo na companhia de sua família. Desenhista, arquiteto e decorador, obteve destaque à frente da construção de diversas obras importantes na região.
} 
como de que não seria possível observá-los devido à posição dos montes. As casas construídas na povoação mediam 50 palmos de frente e eram divididas em quatro ambientes: sala, alcova (quarto), cozinha e varanda fora.

FiguRA 4 - ILUSTRAÇÃO DO PROCESSO DE OCUPAÇÃO DE VIANA

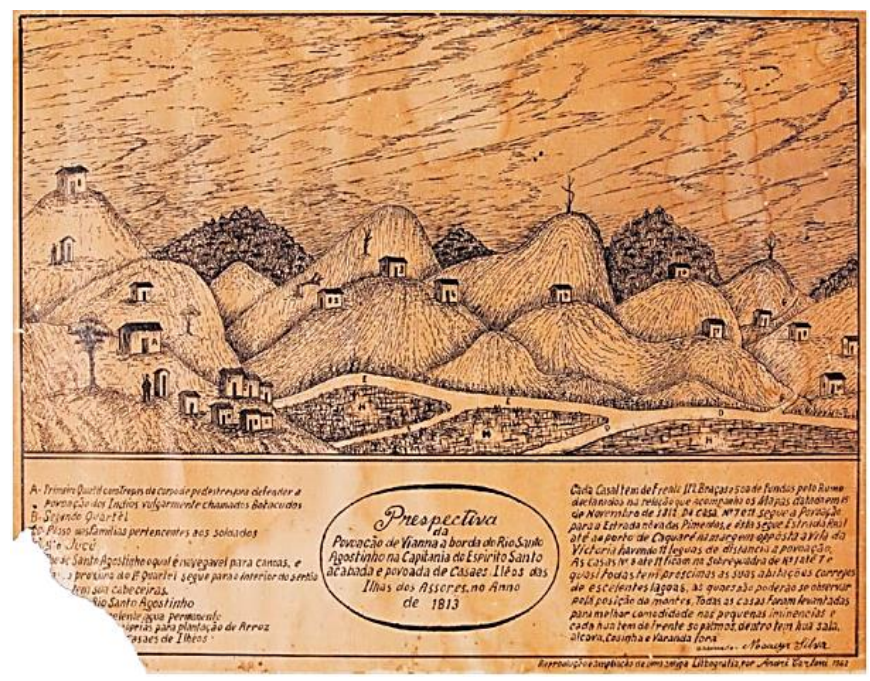

Fonte: Prefeitura Municipal de Viana, 2008.

A documentação oficial indica que apesar dos açorianos terem sido instalados em Viana no ano de 1813, as sesmarias, as casas e os demais benefícios somente foram oficializados a partir da promulgação da Carta Régia de 17 de janeiro de 1814. Essa Carta definia a doação das sesmarias e indicava as culturas agrícolas mais convenientes, bem como regulamentava o uso e o comércio de madeiras.

Por fim, indicava que os açorianos e demais colonos, encaminhados posteriormente à Capitania do Espírito Santo, pudessem demarcar seus terrenos sem quaisquer despesas caso fosse reconhecida a impossibilidade de custeio por questões de pobreza. Além de terras e isenção de impostos, a documentação oficial cita que os açorianos receberam algumas cabeças de bois para auxiliá-los nesse processo inicial de instalação, conforme também documentado no livro de matrícula dos ilhéus.

$\mathrm{Na}$ análise de alguns documentos inferimos que, entre os imigrantes listados, a maioria não era alfabetizada, pois, no local destinado às assinaturas, algumas delas foram redigidas com a mesma caligrafia do corpo do texto, cujo nome estava antecedido da palavra "sinal”, seguida pelo símbolo “+” que, na ocasião, servia para confirmar algum tipo de recebimento. 
Ao final do livro de matrícula dos Ilhéus, encontramos outro documento relevante para o processo de instalação dos imigrantes açorianos: a "Relação dos números e dos donos das casas dos Ilhéus que se acham situados na nova Povoação de Viana" (Arquivo Público do Estado do Espírito Santo, 1815). Emitido por autoridades locais, esse documento, datado de 17 de outubro de 1815, serviu como uma primeira regulamentação da posse dos terrenos, já autorizada pelo Príncipe Regente através da promulgação da Carta Régia de 17 de janeiro de 1814.

O documento, composto por seis páginas, relaciona a localização dos terrenos doados aos açorianos, dividindo-os em sete regiões: Nova estrada de Pimentas - lado Norte (20 assentamentos); Nova estrada de Pimentas - lado Sul (6 assentamentos); Nova estrada da Margem do Rio Santo Agostinho - lado Leste (9 assentamentos); Nova estrada de Parobas - lado Sul (11 assentamentos); Nova estrada de Parobas - lado Norte ( 2 assentamentos); Nova estrada de Parobas - lado leste (2 assentamentos); Sítios Novos (5 assentamentos).

Informações acerca das sesmarias também foram encontradas em outros documentos do Arquivo Público do Espírito Santo, mais especificamente na caixa n 88 da série "Novas Séries" (período de 1814 a 1828), também pertencente ao "Fundo Governadoria". Esse material está organizado em formato de livro e traz, em sua abertura, a seguinte informação: "Registro Geral das Cartas de Confirmação de Sesmarias dos Ilhéus estabelecidos na Povoação de Vianna" (Arquivo Público do Estado do Espírito Santo, 1814b). Os documentos constantes nesse livro possuem um nível maior de detalhamento se comparado à "Relação dos números e dos donos das casas dos Ilhéus que se acham situados na nova Povoação de Viana", analisada anteriormente. Os registros incluem informações que vão além da localização das terras.

A documentação oficial que trata da demarcação das sesmarias aponta que os terrenos estavam localizados essencialmente em três regiões: às margens do Rio de Santo Agostinho e ao longo das Estradas de Parobas (Perobas) e de Pimentas, ou seja, nas proximidades da sede de Viana (atualmente Centro de Viana).

Em suma, a vinda de açorianos para o Espírito Santo, com o intuito de colonizar o Sertão de Santo Agostinho, ocorreu no período entre 28 de novembro de 1812 e 14 de março de 1814 . Todavia, os primeiros imigrantes só foram instalados na região a partir de 15 de fevereiro de 1813 .

Após algum tempo decorrido da instalação, os colonos iniciaram a construção da Igreja Matriz Nossa Senhora da Conceição em Viana. Entre as memórias estatísticas, escritas pelo governador Rubim, a de número 13 indica que "Em quinze de dezembro de 1815 lançou o governador Francisco Alberto Rubim 
a primeira pedra para a edificação da igreja na povoação de Viana, que dedicou a Nossa Senhora da Conceição..." (Rubim, 1840).

Nos anos finais de seu mandato, o governador Rubim passou a residir em Viana, numa casa de campo $^{25}$ construída ao lado da igreja. Essa casa abrigou o intendente geral de polícia, Paulo Fernandes Viana, ${ }^{26}$ quando ele esteve na localidade para participar da festa de inauguração da Igreja Matriz Nossa Senhora da Conceição, em 1817.

$\mathrm{Na}$ fachada da Igreja Matriz encontra-se uma lápide com a seguinte informação: "Estando no Brasil o Príncipe Regente Sr. D. João, sendo intendente geral de polícia Paulo Fernandes Viana, governador desta capitania Francisco Alberto Rubim, no ano de MDCCCXVI".

Erigida no alto de uma colina, a igreja, que ocupa posição de destaque na região, ainda se apresenta como uma das principais referências do patrimônio histórico, artístico e cultural de Viana e, também, do estado do Espírito Santo. ${ }^{27}$ Para a construção desse templo, muitos dos materiais "eram transportados por meio fluvial, através dos Rios Jucu, Jacarandá e finalmente o Santo Agostinho até o porto de Viana, que se localizava na encosta do morro atrás da Igreja" (Pimentel, 2008, p. 175).

Ainda na história presente de Viana, a Festa do Divino permanece sendo realizada na Igreja de Nossa Senhora da Conceição - local onde se desenrolam os principais acontecimentos religiosos do processo ritual, assumindo uma condição de espaço privilegiado da cidade para o contato com o sagrado. Nela também são guardados os principais símbolos da celebração da tradição religiosa açoriana: a Coroa, o Cetro e a Pomba do Divino. Entretanto, essas insígnias somente são expostas e assumem notoriedade no decorrer da realização da festa (Mariano, 2012).

\footnotetext{
25 "O governador começara a construir uma igreja em Santo Agostinho, não longe de Coroaba (fazenda vizinha), razão por que estava residindo nesse lugar. Existe aí um posto militar de guarda contra os selvagens, nessa época, os soldados estavam ocupados em abrir uma estrada para Minas Gerais, para onde já viajara um oficial, por ordem do governador, a fim de abrir caminho através das matas" (Wied-Neuwied, 1989, p. 146).

${ }^{26}$ De acordo com Balestrero (2012, p. 136), durante o período em que Paulo Fernandes Viana esteve à frente da Intendência Geral de Polícia, foram realizadas várias obras na povoação de Viana, todas elas custeadas com os recursos da Corte. Além da igreja e da casa de campo do Governador, o Intendente também foi o responsável pela construção do cemitério, pelas casas dos colonos e pelas casas do padre e do cirurgião.

${ }^{27}$ A Igreja Matriz Nossa Senhora da Conceição foi tombada pelo Conselho Estadual de Cultura em 15/03/1983; Processo n ${ }^{\circ}$ 06655459/93; Resolução n.03/1983 - CEC - inscrita no Livro do Tombo Histórico sob o n.30, à folha 04.
} 
Figura 5 - Igreja Matriz Nossa Senhora da Conceição, Viana - ES

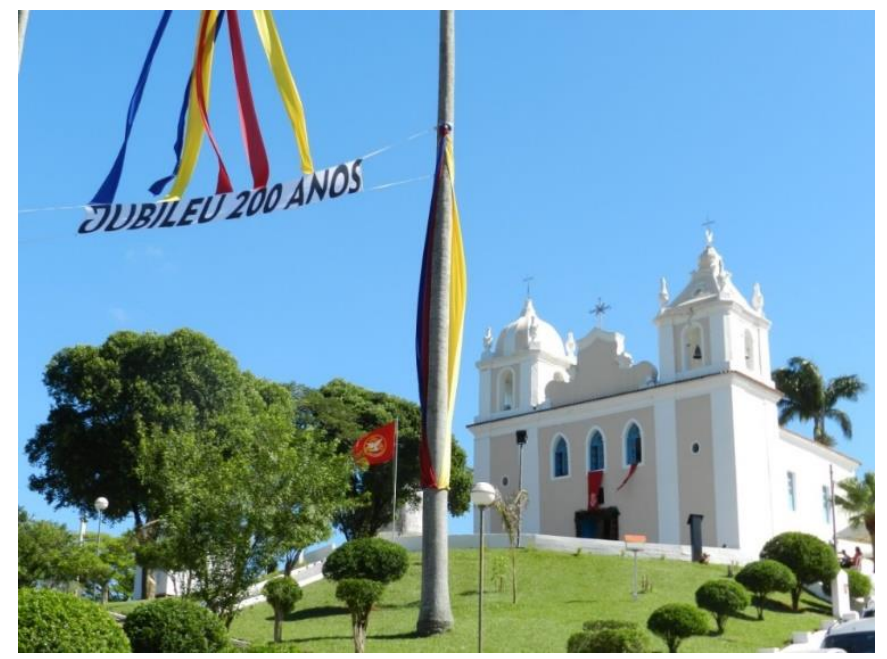

Fonte: Mariano, 2019.

Sendo uma das mais ricas demonstrações religiosas e culturais do estado do Espírito Santo, a Festa do Divino em Viana permanece

imbricada na rede de sociabilidade local e permitindo a construção de um olhar aprofundado sobre a história dessa celebração, suas origens, como veio chegar nesta localidade. Em sua expressão contemporânea, guarda inúmeros traços de similaridade com outras Festas do Divino existentes no Brasil. A comunidade de Viana descreve a festa com patrimônio de valor inestimável que merece ser preservado e divulgado, visando às futuras gerações. Trata-se de uma celebração dotada de religiosidade muito intensa que encontra lugar privilegiado de expressão: na devoção ao Divino Espírito Santo; nas suas redes de sociabilidade baseadas em relações de parentesco e vizinhança; na coletividade da produção da festa; nas formas tradicionais de inserção das famílias na realização dos festejos. (Mariano, 2012, p. 77)

A Festa do Divino Espírito Santo na cidade de Viana - representação da tradição religiosa dos ilhéus açorianos, carregada no trajeto transatlântico de Portugal para o Brasil ainda se mantém após 200 anos de assentamento desse grupo no então Sertão de Santo Agostinho. As particularidades da cultura, da religiosidade e da memória dos imigrantes estão preservadas apesar do hibridismo presente atualmente, onde muitas das características originais apresentam-se mescladas em rituais sagrados e profanos da Festa.

No desenrolar dessa Festa, realizada em Viana, descendentes dos pioneiros açorianos permanecem seguindo um scritp que apresenta, em sua concepção e simbologia, objetos de culto e rituais religiosos que tornam a celebração singular em seus atributos estéticos e performáticos (ao mesmo 
tempo que se assemelha às práticas ainda utilizadas nas Festas do Espírito Santo celebradas nos Açores).

Mesmo com todas as adaptações e/ou ressignificações que ocorrem a cada ano de sua realização, a Festa do Divino consegue manter inalterada a sua essência, ou seja, suas características e seus mecanismos de configuração continuam refletindo a cultura e a religiosidade - heranças da imigração açoriana.

Sendo a única manifestação cultural remanescente da imigração açoriana (do início do século XIX) ainda vigente no Espírito Santo, bem como a Festa religiosa de maior destaque em Viana, ela desempenha um relevante papel na formação da identidade local. Além disso, se apresenta como o elemento primordial de valorização e transmissão da cultura açoriana em Viana, operando como elo entre as memórias da terra de origem e a religiosidade cultivada na terra de acolhimento.

\section{À GUISA DA CONCLUSÃO}

Passados mais de 200 anos da fixação dos açorianos no Espírito Santo, a revisão crítica produzida sobre esse grupo imigrante permanece ainda invisível no além-mar e no Brasil. Este artigo é uma tentativa de tornar conhecida, tanto em nível nacional quanto internacional, inclusive nos Açores, as razões e os processos de deslocamento e estabelecimento de 53 famílias que aportaram em Viana e ainda permanecem desconhecidas na historiografia sociocultural, assim como a manutenção de sua tradição religiosa, celebrada na Festa do Divino Espírito Santo, na cidade onde foram assentados no início do Oitocentos.

Cabe salientar que a presença açoriana no Espírito Santo, face ao assento de outros grupos imigrados ao território - alemães, italianos, pomeranos, espanhóis, sírio-libaneses, entre outros -, ainda é velada pela invisibilidade. A densidade de pesquisas e de trabalhos acadêmicos sobre sua inserção ainda é bastante reduzida e recente. Contudo, pouco a pouco, os açorianos têm sido incluídos na configuração do mosaico identitário capixaba. O reconhecimento de sua presença na diversidade local é conquista que contribui para firmar na História o movimento que os embarcou na travessia do Atlântico, em busca do cais de esperança pretensamente ofertado nos trópicos brasileiros. 


\section{REFERÊNCIAS}

Arquivo Público do Estado do Espírito Santo. (1813a). Correspondência e atos do Príncipe Regente - Governo do Reino entre os anos de 1813 e 1817. [Correspondência enviada ao governador Rubim em 23/04/1813. Fundo Governadoria. Série Acciolly. Caixa 002]. Vitória.

Arquivo Público do Estado do Espírito Santo. (1813b). Correspondência e atos do Príncipe Regente - Governo do Reino entre os anos de 1813 e 1817. [Correspondência enviada ao governador Rubim em 04/12/1813. Fundo Governadoria. Série Acciolly. Caixa 002]. Vitória.

Arquivo Público do Estado do Espírito Santo. (1814a). Livro de Matrícula dos Ilhéus situados na Povoação de Viana. [Relação dos casais situados na nova Povoação de Viana. Fundo Governadoria. Série 751. Livro 17]. Vitória.

Arquivo Público do Estado do Espírito Santo. (1814b). Carta de Sesmarias - Período 1814 a 1828. [Registro Geral das Cartas de Confirmação de Sesmarias dos Ilhéus estabelecidos na Povoação de Vianna. Fundo Governadoria. Série Novas Séries Documentais. Caixa 088]. Vitória.

Arquivo Público do Estado do Espírito Santo. (1815). Livro de Matrícula dos Ilhéus situados na Povoação de Viana. [Relação dos números e dos donos das casas dos Ilhéus que se acham situados na nova Povoação de Viana. Fundo Governadoria. Série 751. Livro 17]. Vitória.

Arquivo Público do Estado do Espírito Santo. (1822). Registro de Ofícios do Governo Provisório [Ofício de onze de junho de 1822, da Junta Governativa ao ministro José Bonifácio. Fundo Governadoria. Série 751. Livro 027]. Vitória.

Balestrero, H. (2012). Subsídios para o estudo da geografia e da história do município de Viana. JEP Gráfica.

Banck, G. (2011) Caçar com gato: escassez de recursos e relações sociais no Espírito Santo (K. van den Bergen, trad.) [Tese de doutorado, Universidade de Amsterdam]. https://drive.google.com/file/d/161ywSaHCdOb2RrP5r8otqVt_1D5H6tzB/view

Becker, H. S. (2009). Falando da sociedade: ensaios sobre as diferentes maneiras de representação. Jorge Zahar.

Bittencourt, G. (2008). A Transmigração da corte e sua influência no desenvolvimento do Espírito Santo. Revista do Instituto Histórico e Geográfico do Espírito Santo, (62), 9-34. https://doi.org/10.17648/ihgp.v7i01.202

Carvalho, E. (2008). Política e economia mercantil nas terras do Espírito Santo (1790 a 1821) [Dissertação de mestrado, Universidade Federal do Espírito Santo]. RiUfes. https://repositorio.ufes.br/bitstream/10/3360/1/tese_3254_Enaile_Flauzina_Carvalho.pdf

Cordeiro, C., \& Madeira, A. (2003). A emigração açoriana para o Brasil (1541-1820). Arquipélago, 2(7), 99-122.

Coutinho, D. J. C. (2002). O Espírito Santo em princípios do século XIX. Trecho dos apontamentos das visitas pastorais de D. José Caetano da Silva Coutinho, Bispo do Rio de Janeiro, correspondente à sua passagem por Vitória durante as visitas que fez ao Espírito Santo nos anos de 1812 e 1819. Lei Rubem Braga PMV.

Dadalto, M. C. (2015). Representações sociais na imigração de retorno à Itália. Métis: História \& Cultura, 13(27), 311-321. 
Decreto de $1^{\circ}$ de setembro de 1808. Presidência da República - Casa Civil. http://www.planalto.gov.br/ccivil_03/decreto/historicos/dim/DIM-1-9-1808.htm

Derenzi, L. (1965). Biografia de uma ilha. Prefeitura Municipal de Vitória; Secretaria Municipal de Cultura e Turismo.

Flores, M. B. (2000). Povoadores da Fronteira: os casais açorianos rumo ao Sul do Brasil. EdUFSC.

Fortes, J. B. (1999) Os casais açorianos: Presença lusa na formação sul-rio-grandense. Martins Livreiro.

Gibney, M. (2009). Precarious residents: migration control, membership and the rights of noncitizens. United Nations Development Programme.

Grosseli, R. (2009). Colônias Imperiais na Terra do Café: Camponeses trentinos (vênetos e lombardos) nas florestas brasileiras. Espírito Santo 1874-1900 (M. Sarcinelli, trad.). Senado Federal, Conselho Editorial.

Guimarães, A. (2012). Racismo e antirracismo no Brasil. Editora 34.

Honneth, A. (2006) La Société du mépris. Vers une nouvelle théorie critique (O. Voirol, P. Rusch \& A. Dupeyrix, trad. para o francês). La Découverte.

IBGE (Instituto Brasileiro de Geografia e Estatística). Viana (ES). Cidades e Estados. https://www.ibge.gov.br/cidades-e-estados/es/viana.html

Lemos, N. (2008). Paulo Fernandes Viana, o Intendente-Geral de Polícia na corte joanina (18081821). Cadernos de História, 6(2), 16-26.

Levy, M. (1974). O papel da migração internacional na evolução da população brasileira (1872 a 1972). Saúde Pública, (8), 49-90. https://doi.org/10.1590/S0034-89101974000500003

Mariano, F. P. (2012). Patrimônio e Memória: o Divino em Viana do Espírito Santo [Dissertação de mestrado, Universidade Federal do Espírito Santo]. RiUfes. http://repositorio.ufes.br/bitstream/10/2091/1/tese_5962_Disserta\%C3\%A7\%C3\%A3o\%20Fabiene.pdf

Mariano, F. P. (2019). A Festa do Divino em Viana no século XXI: memórias afetivas na construção de uma açorianidade capixaba. [Tese de doutorado, Universidade Federal do Espírito Santo]. Pró-Reitoria de Pesquisa e Pós-Graduação Ufes. http://portais4.ufes.br/posgrad/teses/tese_8701_FABIENE\%20Tese\%20vers\%E3o\%20Novembro\%20\%282\%29.pdf

Matos, M. (2013). Portugueses: Deslocamentos, experiências e cotidiano: São Paulo séculos XIX $e X X$. Edusc.

Novaes, M. (1964). História do Espírito Santo. Fundo Editorial do Espírito Santo.

Oliveira, J. (2008). História do estado do Espírito Santo (3. ed.). Arquivo Público do Estado do Espírito Santo; Secretaria de Estado da Cultura.

Piazza, W. (1998). A colonização de Santa Catarina. Lunardelli.

Pimentel, M. (2008). Os Açorianos na Capitania do Espírito Santo e a fundação da Povoação de Viana. Revista do Instituto Histórico e Geográfico do Espírito Santo, (62), 153-181.

Prefeitura Municipal de Viana. (2008). Viana em Muitos Olhares. PMV.

Presidência da República. (1808). Decreto de $1^{\circ}$ de setembro de 1808. Manda vir da Ilha dos Açores 1.500 familias para a Capitania do Rio Grande do Sul. http://www.planalto.gov.br/ccivil_03/decreto/historicos/dim/DIM-1-9-1808.htm 
Razera, G. (2016). O Brasil e o "brasileiro" em O primo Basílio: Análise sobre Basílio de Brito. UFRGS.

Rubim, F. (1840). Memórias para servir à história: até o ano de 1817 e breve notícia estatística da Capitania do Espírito Santo, porção integrante do Reino do Brasil. Imprensa Nevesiana.

Riley, C. G. (2003). A emigração açoriana para o Brasil no século XIX: braçais e intelectuais. Arquipélago, (7), 143-172.

Rodrigues, J. D., \& Rocha, G. P. (2008). A emigração açoriana para o Brasil: ritmos e destinos. In M. I. Matos, F. Sousa \& A. Hecker (eds.), Deslocamentos e histórias: os portugueses (pp. 245-258). Edusc.

Saint-Hilaire, A. (1974). Viagem ao Espirito Santo e Rio Doce. Itatiaia.

Sayad, A. (2000) O retorno: elemento constitutivo da condição do imigrante. Travessia, (13), pp. 7-32.

Santos, E. (2005). Vias de comunicação, conquista territorial e colonização estrangeira no Espírito Santo do séc. XIX: a gênese do pensamento político capixaba. Dimensões, (17), 47-68.

Silva, S. S. (2012). A emigração açoriana para o Brasil, por meados do século XIX , e a questão da "escravatura branca". História: Questões \& Debates, (56), 37-61. https://doi.org/10.5380/his.v56i1.28638

Silva, S. S. (2019). Emigração açoriana entre a história e a memória. Memória e Identidade Insular. In D. N. Chaves (ed.) Religiosidade, festividades e turismo nos arquipélagos da Madeira e Açores (pp. 89-116). CHAM Universidade dos Açores.

Sousa, F., \& Ferraria, M. (2009). A emigração portuguesa para o Brasil e as origens da Agência Abreu. In F. Sousa, I. Martins \& I. Matos (eds.), Nas duas margens: os portugueses no Brasil (pp. 13-32). Afrontamento.

Viana, P. (1892). Abreviada Demonstração dos Trabalhos da Polícia. Revista do Instituto Histórico e Geográfico Brasileiro - RIHGB, (55), IV, Parte I, 373-380.

Wied-Neuwied, M. (1989). Viagem ao Brasil. APGIQ. 